\title{
Different Seed Selection and Conservation Practices for Fresh Market and Dried Chile Farmers in Aguascalientes, Mexico ${ }^{1}$
}

\author{
Kraig H. Kraft*2, José de Jesús Luna-Ruíz ${ }^{3}$, and Paul Gepts ${ }^{2}$ \\ ${ }^{2}$ Department of Plant Sciences, University of California, Davis, CA, USA \\ ${ }^{3}$ Universidad Autónoma de Aguascalientes, Aguascalientes, Mexico \\ *Corresponding author; e-mail: kraigkraft@gmail.com
}

\begin{abstract}
Different Seed Selection and Conservation Practices for Fresh Market and Dried Chile Farmers in Aguascalientes, Mexico. The process of selecting and saving seed is the most basic and oldest of agricultural practices. In today's modern and highly capital-intensive agriculture, seeds are often treated like another chemical input. This study sought to examine seed selection and saving practices among chile farmers in Aguascalientes, Mexico, where both industrial and traditional agriculture are practiced. We observed a clear division among farmers who plant chile peppers commercially. Sixty-eight chile pepper farmers were surveyed in order to document seed selection and saving practices. Fifteen respondents $(22 \%)$ planted chile peppers destined for the fresh market and all utilized purchased commercial seed of F1 hybrid varieties. Fifty-three farmers $(78 \%)$ planted chiles to be dried and either saved their own or purchased seeds that others had saved and selected. Farmers who saved their own seed sought to maintain an ideotype, rather than directionally select for certain traits, much like Cleveland et al. (2000) chronicled in central Mexican maize farmers. Farmers would benefit from a participatory plant-breeding program in order to maintain productive seed stock for the continued cultivation of dried chile pepper in the state.
\end{abstract}

\begin{abstract}
Diferencias en las practicas de selección y conservación de semillas que realizan los productores de chiles frescos y secos en Aguascalientes, México. La selección y conservación de semillas son las prácticas agrícolas más básicas y antiguas que ha realizado el ser humano. En la agricultura intensiva moderna, las semillas son manejadas como otro insumo de los agroquímicos. En este trabajo se estudiaron las prácticas de selección y conservación de semillas entre los productores de chile en Aguascalientes, México. Se observo una clara división entre los agricultores que cultivan chiles para el mercado en fresco y los productores de chiles secos. Se encuestaron 68 agricultores para documentar las prácticas de selección de semilla y las prácticas para su conservación. Quince o veintidós por ciento de los encuestados siembra chiles para el mercado fresco y todos ellos comparan y utilizan semillas comerciales de variedades híbridas F1. El 53 de los encuestados o 78\% siembran chiles para el mercado en seco, y todos ellos guardan su propia semilla, o la compran con otros productores que seleccionan y mejoran su propia semilla. Los agricultores que guardan sus propias semillas tratan de mantener un ideotipo de chile en lugar de seleccionar rasgos determinados que podrían mejorar y modificar sus materiales criollos, como lo reporta Cleveland y Soleri Cleveland et al. (2000) con productores de maíz en México. Los agricultores de Aguascalientes podrían beneficiarse con un programa de mejoramiento participativo enfocado a mantener una reserva de semillas criollas mejoradas para hacer más viable y atractivo el cultivo de chile seco en el estado.
\end{abstract}

Key Words: Seed saving, landraces, seed selection, Capsicum annuum, Mexico.

\section{Introduction}

The importance of identifying and maintaining crop diversity is widely recognized as a global

\footnotetext{
${ }^{1}$ Received 30 March 2010; accepted 20 September 2010; published online 16 October 2010.
}

priority. While efforts such as the Svalbard Global Seed Vault and other germplasm repositories seek to safeguard the agricultural treasures of the world, they represent a static picture of diversity and often can marginalize the dynamic process of farmers whose activities generate and maintain 
diversity. The role of farmer selection in the creation and maintenance of crop diversity has only recently been investigated in staple crops such as wheat, maize, potatoes, and cassava (Abay et al. 2008; Bellon 1996; Bellon et al. 2003; Brush and Meng 1998; Cleveland et al. 2000; Dyer and Taylor 2008; Jarvis and Hodgkin 1999; Louette and Smale 2000; Perales et al. 2003). To date there have been limited attempts to examine their role in creating and conserving diversity in horticultural crops.

A horticultural crop of great importance globally, the chile pepper (Capsicum annuum L., "chile" in Spanish and the preferred common name) is one of the oldest crops in the Americas. Archaeological evidence points to the collection and consumption of wild chile peppers from over 8,000 years ago and the cultivation of domesticated peppers starting around 6,000 years ago (Perry and Flannery 2007). The long history of cultivation and the high level of topographic and cultural heterogeneity have given rise to a large number of landraces, or traditional varieties. All of these varieties can be divided into two distinct classes. The first are chiles that are used for fresh consumption or for immediate post-harvest processing such as canning or pickling. Examples are Jalapeño, Serrano, Ancho/Poblano, Caloro, Húngaro, Bell, Anaheim, Wax, and Güero. The second are dried chiles-either sun-dried or in a gas-powered commercial dryer (secadora) and then sold as a whole dried pod, or ground into a powder; examples are Guajillo, Pasilla, Cascabel, Ancho, Puya, Huacle, Piquín, and Chile de arbol. In Mexico, chile peppers produced for fresh consumption are predominantly grown from hybrid seeds, whereas varieties that are to be consumed dry are landraces, with farmer-saved seed (Cabañas Cruz and Galindo Gonzales 2004). For the purposes of this paper, we define a landrace as a population that is presumably adapted to local agroclimatic conditions, has some genetic variation, and has been developed and maintained by farmers (Teshome et al. 1999). In many cases, the local term for landrace-criolla is used in place of landrace. In this paper, both terms are used interchangeably.

The process of seed saving of local crop varieties is known to differ among farmers and crop species. For many staple crops, seed selection by farmers occurs postharvest and includes consumer preferences, such as taste, color, processing quality, and suitability for traditional foods
(Almekinders and Elings 2001). In his book Farmers' Bounty, Brush (2004) summed up the two predominant questions that are of interest in studies of farmer selection of crop seed: (1) What criteria are employed for selection and (2) What is the process of selection? For chile peppers, we considered three stages of selection. The first was selection in the field-Are there characteristics of the plant in the field that the farmer selects for and then identifies to be seed sources? The second stage is fruit selection, where individual fruits are selected based on the farmer's criteria and set aside for seed. The third stage is seed selection, where extracted seeds are selected based on an additional set of criteria. Within this plant developmental framework, we asked the following questions: Are there demographic differences between farmers who save seed and those who plant hybrids? Among those who save seed, are there differences in how farmers maintain and select seed? If differences are found, what are the factors that explain these differences? What are the mechanisms by which farmers maintain and generate diversity in these landraces?

\section{Methods}

STUdy Site

Aguascalientes is a small state $(5,500 \mathrm{sqkm})$ located in the central highlands of Mexico, bordered by Zacatecas to the north and Jalisco to the South. A stopping place on the old Camino Real, today the capital of Aguascalientes is a passing point on the way to the U.S. Border, or from the industrial capitals of Northern Mexico-Juarez, Torreon, Monterrey-to Guadalajara or to Mexico City. The agricultural industry in the state is dominated by dairy and beef, followed by guavas, chiles, grapes, lettuce, and garlic (INEGI 2005). Of the 11 municipalities in Aguascalientes, chiles are principally grown in Asientos, Cosio, Rincon de Romos, Tepezala, and San Francisco de los Romo. These municipalities have areas located at 1,800 to 2,000 masl and are clustered in the northern part of the state.

\section{SURVEY}

The state committee on plant health (Comité Estatal de Sanidad Vegetal) has cataloged every farmer who plants solanaceous crops (tomatillo, tomato, potato, chiles) in order to prevent and combat outbreaks of pests and diseases, such the tomato psyllid (Paratrioza cockerelli). 
A list of all producers of solanaceous crops in the state during the 2007 growing season was generated by the comitês field technicians and made available. From this total list, 180 were identified as chile producers who had produced more than 0.25 ha of chiles in 2007. A random number generator chose 70 producers to survey for their criteria and process of seed selection. Of the 70, 2 were unavailable for the survey, leaving a final number of 68 participants. The first section of the survey recorded demographic information and basic information about their farm. The second section of the survey focused on the types of chiles grown and the farmer's perception of their qualities. The third and final section focused on seed saving, how and where the process was conducted, and how seeds were stored for the next year. The survey was developed in collaboration with Dr. José Luna Ruíz of the Universidad Autónoma de Aguascalientes and with input from the leadership of the Secretaría de Agricultura, Ganadería, Desarollo Rural, Pesca y Alimentación, SAGARPA, and the Sistema Producto Chile in Aguascalientes (the state chile farmer organization).

From January 2008 to March 2008, K. Kraft traveled to the towns identified for each selected producer. At each location, technicians from the Comité Estatal de Sanidad Vegetal and local people assisted in locating survey participants. Participants were visited in their fields and/or at their residences. The survey was conducted orally by K. Kraft. When the name given by the Comité Estatal de Sanidad Vegetal did not correspond to who was making management decisions on the land, the individual who did the farming was surveyed. The survey included a mix of openended questions and categorical questions, which can be seen as part of the supplementary information included in this paper. There were no responses to choose among in open-ended questions, the participants answered and the answers were grouped later, whereas categorical questions had a number of options that the participant had to choose from. Half of the respondents were also photographed with their permission.

\section{ANALYSIS}

Analyses of the survey data were conducted using Excel (Microsoft Corporation 2007), JMP (SAS Institute 1989-2004), (2002-2003). For open-ended questions, answers were grouped according to similarity. For many of the varietal questions, or other questions that had multiple potential responses, tables were generated to present the data. Summary statistics were calculated using Excel, JMP, and SAS. For the comparisons of means, many statistical tests use assumptions that the means we are comparing are samples from unknown population sizes. Since the entire population of chile farmers in the state of Aguascalientes is 180, the standard error terms of the means is corrected by applying a finite population correction $f p c$, which is given by $f p c=(\mathrm{N}-\mathrm{n}) /(\mathrm{N}-1)$, where $\mathrm{N}$ is the total number of chile farmers (180) and $\mathrm{n}$ is the number belonging to each respective group (hybrid farmer, criollo farmer) (Levy and Lemeshow 1991). For comparing farmers planting hybrid seeds with those planting only criolla seeds, we included all farmers who used any hybrid seed in the first group even though some may have also used criolla varieties. For comparison of these subgroups, 95\% confidence intervals were generated by multiplying the $f p c$-corrected standard error of the mean by 1.96 (95\% of the population exists within about two standard deviations of the mean). If the confidence intervals did not overlap, we concluded that the means were different at a minimum significance level of $p<0.05$. We also used a Pearson's chi square or Fisher's exact probability approach to test for differences in the categorical responses of farmer education level and farm irrigation type between farmers of hybrid and criollo seed types.

\section{Results \\ DEMOGRAPHIC RESULTS}

The survey began by inquiring about general demographic data. Of the 68 participants who completed the survey, all were males (Table 1). While females participated in labor, farming and decision making were solely male activities among the participants. The average age of participants was 53 years, but with a wide spread in age from 22 to 88 years. The farmers surveyed had an average of 33 years of farming experience, with a large range from 3 to 75 years. The majority of respondents had little or cursory levels of formal education, while $20 \%$ of respondents reported attending some college 
TABle 1. Demographic Characteristics of THE SURVEY PARTicipants.

\begin{tabular}{lll}
\hline \hline Demographic questions & Value \\
\hline Number of completed surveys & 68 & 0 Female \\
Sex & 68 Male & $22-88$ Range, 14.0 SD \\
Age (years) & 53.5 Average & $3-75$ Range, 18.5 SD \\
Years of previous agricultural experience & 33.3 Average & $11 \%$ \\
Level of formal education & Never attended school & $42 \%$ \\
& Some primary education & $22 \%$ \\
& Some secondary education & $22 \%$ \\
\hline
\end{tabular}

classes. There were a few Ingenieros Agrónomos (those with university-level agricultural degrees) in the survey pool and others that completed non-agricultural university degrees.

Of the 68 farmers surveyed, $86 \%$ said they would continue to plant chile peppers in 2008 (Table 2). The remaining $14 \%$ who were not planting stated that poor yields, high costs of production, or a lack of available land were reasons for not planting chiles in 2008. For this group of respondents, the remaining survey questions were directed at their last year of planting. On average, chile farmers plant three additional crops besides chiles. The most common other crops planted (in order of response numbers) were maize, beans, garlic, tomatoes, alfalfa, and lettuce. There was a large disparity among the respondents in the total acreage planted and the acreage planted to chile pepper. While the mean total acreage was 22 ha, the minimum was 2 ha and the maximum was 200 ha. The large disparity in total acreage is reflected in a standard deviation of 35 ha larger than the mean and a median of 10 ha. Similarly, the mean acreage planted to chile pepper is skewed in the same direction, with a mean of 5 ha, with a minimum of 0.5 ha, a maximum of 40 ha, a standard deviation of 6 ha, and a median of 2 ha.

\section{Varieties of Chiles Grown in Aguascalientes}

The most popular chile varieties grown by the respondents were Pasilla, Guajillo, Ancho, and Caloro (Table 3). Of the chile grown by the survey participants, $69 \%$ are dried varieties, with Guajillo and Pasilla making up 65\% of all chiles grown - both of these are landraces-while the next most frequent answer, Ancho, can be sold both as a fresh or dried chile. The remaining 19\% comprises a number of varieties that are predominantly grown for fresh consumption.

\section{Farmer Selection Strategies and Criteria}

Looking at the provenance of these varieties, $9 \%$ of the respondents planted both hybrid and criolla varieties, while $13 \%$ planted only hybrids, and $78 \%$ planted solely criollas. Of those planting criolla seed, $67 \%$ save some portion of seed to replant. Of those who practice seed selection for replanting, there are a number of different strategies that are practiced (Fig. 1). The most common selection strategy was postharvest selection of the fruit. This was followed by a combination of selection in the field and postharvest selection of fruits and then by a three-step selection strategy of field, fruit, and seed selection. Forty-one percent of respondents applied only

TABLE 2. CHARACTERISTICS OF THE FARMS AND CROP ACREAGES OF THE FARMERS SURVEYED IN THIS STUDY.

\begin{tabular}{ll}
\hline \hline Characteristic & \multicolumn{1}{c}{ Value } \\
\hline Respondents who will plant chiles in 2008 & $86 \%$ \\
Average number of other crops planted & 3 \\
Total acreage & 22 ha average, 2 ha min, 200 ha max \\
Acreage planted to chile peppers & 5 ha average, 0.5 ha min, 40 ha max \\
Irrigation & $32 \%$ Drip, 68\% Furrow \\
Number of chile varieties planted & 2 average, 1 min, 7 max \\
\hline
\end{tabular}


TABLE 3. CHILE VARIETIES GROWN BY SURVEY PARTICIPANTS $(\mathrm{N}=68)$.

\begin{tabular}{lccc}
\hline \hline Chile Type & $\mathrm{N}$ & $\%$ & Culinary Use \\
\hline Pasilla & 48 & $33 \%$ & Dried \\
Guajillo & 47 & $32 \%$ & Dried \\
Ancho & 14 & $10 \%$ & Fresh-Dried \\
Caloro & 10 & $7 \%$ & Fresh \\
Jalapeño & 6 & $4 \%$ & Fresh \\
Hungaro & 8 & $5 \%$ & Fresh \\
Serrano & 4 & $3 \%$ & Fresh \\
Anaheim & 3 & $2 \%$ & Fresh \\
Mulato & 2 & $1 \%$ & Dried \\
Puya & 2 & $1 \%$ & Dried \\
Bell & 1 & $1 \%$ & Fresh \\
Huacle & 1 & $1 \%$ & Dried \\
\hline
\end{tabular}

one selection step (30\% fruit only, 11\% field only, $0 \%$ seed only), whereas the remainder employed two or even all three steps.

\section{Field Selection Criteria}

Farmers used different criteria at each selection step. The field selection criteria identified by the participants are listed in Table 4 . The criteria that were most commonly identified by farmers for infield selection of chile peppers were these: Healthy plant (planta sana), a heavy fruit load (plantas cargadas), size of the fruit (tamaño del fruto), shape of the fruit (forma del fruto), and the uniformity of the fruit (fruto uniforme). While nearly $34 \%$ of the farmers surveyed evaluated plant health, $42 \%$ used fruit characteristics, namely, size, shape, and uniformity.

\section{Fruit and Seed Selection Criteria}

Table 5 shows the criteria used for fruit selection as identified by the survey respondents. The results are similar to those for field selection. By far the most frequent response was fruit size. Nearly $50 \%$ of the respondents identified size as the most important fruit criterion. Following size, form, color, and earliness were other prized criteria. There were only three different criteria used for seed selection. Respondents selected seeds on the basis of color, size, and weight, in decreasing order of frequency.

\section{SeEd Sources}

The respondents had quite diverse responses to the inquiry of where their seeds came from (Table 6). While many of them referred to geographic locations (e.g., Zacatecas), others referred to their sources as neighbors or family members. The primary source of criolla seeds was Zacatecas, followed by neighbors, then Querétaro. However, a substantial proportion $(32 \%)$ of the responses were 14 different locations, which were each identified only once or twice.

Looking at comparisons between those farmers who planted criollas and those who did not, criollo farmers were found to plant fewer crops-a lower total and a lower chile acreage-and to plant fewer chile varieties than those who planted hybrids (Table 7). Farmers cultivating hybrids

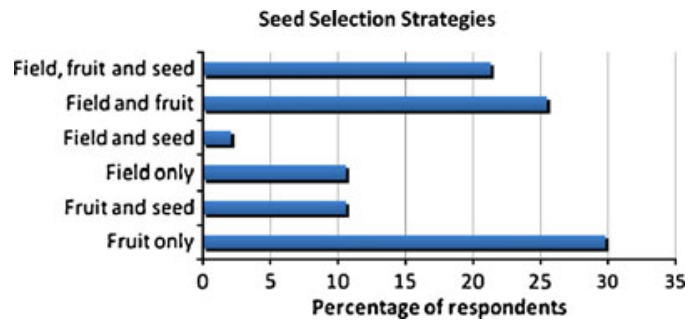

Fig. 1. Selection regimes of farmers who saved seed for replanting the following year. 
Table 4. Field Selection CRiteria employed by survey participants. Many participants answered WITH MORE THAN ONE CRITERION.

\begin{tabular}{llrr}
\hline \hline Field selection criteria & Equivalent criteria in English & $\mathrm{N}$ & $\%$ \\
\hline Plantas Sanas & Healthy plants & 20 & $34 \%$ \\
Plantas Cargadas & Loaded plants & 7 & $12 \%$ \\
Tamańo del fruto & Fruit Size & 6 & $10 \%$ \\
Forma del fruto & Fruit Form & 6 & $10 \%$ \\
Fruto Uniforme & Uniform fruit & 4 & $7 \%$ \\
Buenos frutos & Good fruits & 2 & $3 \%$ \\
Rendimiento & Yield & 2 & $3 \%$ \\
Otros & Other & 11 & $19 \%$ \\
\hline
\end{tabular}

also had significantly higher levels of education and were more likely to have drip irrigation as shown by the Pearson's chi-square $(\mathrm{p}=0.004)$ and Fisher's exact probability tests $(\mathrm{p}=0.00002)$.

When considering the different markets for chiles (Table 8), there were two main options, with a large number of alternatives. Fresh chiles were primarily sold to a wholesale market, the Centro Comercial Agropecuario (Mercado de Abastos) in Aguascalientes (mentioned by $15 \%$ of the informants) or, more rarely, the Mercado de Abastos in Guadalarajara, the second largest Mexican city, three hours by car from Aguascalientes. But dried chiles were sold to individuals/ groups who do postharvest processing (drying and packing), known locally as "secadoras" (literally, "dryer"-mentioned by $38 \%$ of informants), or sold directly to smaller middlemen, known in Mexico as "coyotes" (mentioned by 25\% of informants), who come to the farms with their teams and pick the fields themselves.

\section{Discussion}

\section{Local Seed System for Dried Chiles}

The data reveal a snapshot of a farming landscape in flux. The distribution of land is skewed towards a small subgroup of large-scale farmers. While farmers who plant fresh chiles and hybrids made up $22 \%$ of all respondents, they plant $43 \%$ of the total acreage and $33 \%$ of the chile acreage. Removing the two largest criollo farming landholders, these numbers increase to $50 \%$ and $39 \%$, respectively. These farmers use machine labor and technological inputs-from machinery to prepare the fields, drip irrigation, plastic mulch, greenhouse germination, and hybrid seeds. It is the combination of this technological package that brings about high yields (and hopefully increased profits). However, hybrid seeds have their limits at present. Hybrid seeds were used in Aguascalientes exclusively for the production of green chiles. Hybrids have displaced all the landraces of green chile in Aguascalientes (J. Luna Ruíz, personal communication). One prominent example is the Ancho. Before the arrival of Ancho hybrid seeds, Ancho landraces were grown and selected to be dual-purpose. Depending on the prices, these chiles could be harvested green for the fresh market, or if the price is too low, the harvest would be left to color and ripen and then dried and sold. However, today there are two types of Ancho varieties: The hybrid varieties of Ancho for the fresh market and the criolla varieties of Ancho for the dried market.

In contrast, every single farmer surveyed who produced dried chile planted a criolla variety. This

TABle 5. CRIteria IDENTIFIED FOR SEED SELECTION BY SURVEY PARTICIPANTS. PARTICIPANTS OFTEN IDENTIFIED MORE THAN ONE CRITERION.

\begin{tabular}{llrr}
\hline \hline Fruit selection criteria & English translation & $\mathrm{N}$ & $\%$ \\
\hline tamaño & Size & 31 & $49 \%$ \\
forma & Shape & 17 & $27 \%$ \\
color & Color & 4 & $6 \%$ \\
primeros & First (earliest) & 3 & $5 \%$ \\
bien hechos & Well made & 2 & $3 \%$ \\
otros & Others & 6 & $10 \%$ \\
\hline
\end{tabular}


TABle 6. IDENTIFIED CRIOLLA SEed SOURCES by PARTICIPANTS.

\begin{tabular}{llrr}
\hline \hline Seed source & \multicolumn{1}{c}{ English translation } & N & $\%$ \\
\hline Zacatecas & State of Zacatecas & 12 & $23 \%$ \\
Vecinos & Neighbors & 11 & $21 \%$ \\
Querétaro & State of Queretaro & 7 & $13 \%$ \\
Secadora & Drying facility & 3 & $6 \%$ \\
Pabellón de Arteaga & Municipality of Pabellón de Arteaga & 3 & $6 \%$ \\
Otras & Others & 17 & $32 \%$ \\
\hline
\end{tabular}

seed may have originated on their farm, or it may have been purchased. Frequently, the seed comes from neighbors or specialists who are renowned for having high quality seed and high yielding varieties.

Why do criolla varieties persist solely among dried chiles? We believe that two factors contribute greatly to their persistence: (1) The as-of-yet unknown genetic mechanisms involved in dry biomass accumulation in the fruit and their role in desired taste and flavor and (2) the more lax requirements of the dried chile market-uniformity of fruit size/shape/color is not as paramount in the dry chile market as it is for fresh chiles.

The most common comment regarding the reasons why hybrids were not used for dried chile production was that they produce dried chiles that weigh very little ("son muy apapelados") — the chiles are very "papery" - upon drying, the skin dries to a thin, brittle shell with very little dry matter, resulting in very low dry yields. This contrasts with the criolla varieties, which produce smaller chiles yet retain much more weight when dried. Son más carnudos - they are much "meatier." Taking a step back and looking at this from a breeding perspective, Quantitative Trait Loci or QTLs have been identified for fruit size and shape in chile peppers (Zygier et al. 2005). No comparable study has been performed to our knowledge to identify specific QTLs for pericarp fresh or dry weight. Yet, this information could assist in developing pepper cultivars with increased pericarp fleshiness. There have been studies that looked at the relationship between dry yield and wet yield in forage crops, where there is an indirect relationship (Conaghan et al. 2008), but there is no comparable research for horticultural crops, with the exception of the tomato in which the amount of soluble solids is of paramount importance for processing tomato compared to fresh market tomato (Bai and Pim 2007). The increase in yield observed in hybrid varieties of chile is due to increased uptake and sequestration of water in the fruit (J. Luna Ruíz, unpublished data). This creates a heavy fruit with a taut, unwrinkled exterior-a great product to market fresh; however, all the water in the fruit makes it unsuitable for drying. There is anecdotal evidence to support this. Farmers identify high yielding criolla varieties for drying based on a rough 1:5 ratio for dry weight to fresh weight $(1 \mathrm{~kg}$ of dry chiles from $5 \mathrm{~kg}$ of fresh

TABLE 7. COMPARISONS BETWEEN FARMERS WHO PLANT HYBRID SEEDS AND THOSE WHO PLANT CRIOLLOS.

\begin{tabular}{|c|c|c|c|c|}
\hline \multirow[b]{3}{*}{ Farmer variable } & \multicolumn{4}{|c|}{ Type of cultivated variety } \\
\hline & \multicolumn{2}{|r|}{ Hybrid } & \multicolumn{2}{|r|}{ Criollo } \\
\hline & Mean & $\pm($ Standard Error*1.96) & Mean & $\pm($ Standard Error*1.96) \\
\hline Age of farmer (years) & 50.1 & \pm 5.3 & 54.5 & \pm 3.4 \\
\hline Years of farming experience & 27.7 & \pm 6.9 & 34.9 & \pm 3.9 \\
\hline Number of other cultivated crops & 3.9 & $\pm 0.4 *$ & 2.8 & \pm 2.1 \\
\hline Total cultivated area (ha) & 52.7 & $\pm 19.8^{*}$ & 19.5 & \pm 4.7 \\
\hline Cultivated area with chiles (ha) & 7.8 & $\pm 2.0 *$ & 4.4 & \pm 2.7 \\
\hline Number of cultivated chile varieties & 3.8 & $\pm 0.8 *$ & 1.7 & \pm 2.0 \\
\hline Number of farmers in the sample & \multicolumn{2}{|r|}{15} & \multicolumn{2}{|c|}{53} \\
\hline
\end{tabular}

Mean $\pm\left(\right.$ Standard Error*1.96) followed by an asterisk $\left(^{*}\right)$ are significantly different $(P=0.05)$. 
TABLE 8. BuYERS/MARKETS OF THE CHILES PRODUCED By SURVEY PARTICIPANTS. INCLUDES BOTH DRIED AND FRESH CHILES.

\begin{tabular}{lcc}
\hline \hline Location & Number of responses & \% of Total \\
\hline Secadora & 27 & 37.50 \\
Coyotes & 19 & 26.39 \\
C.C. Agropecuario (Ags.) & 11 & 15.28 \\
Loreto (Zac) & 3 & 4.17 \\
Mercado de Abastos (Guadalajara) & 2 & 2.78 \\
Mercado de Abastos (Oaxaca) & 2 & 2.78 \\
Propio comercialadores (own marketing) & 2 & 2.78 \\
Central de Abastos, (Mexico, D.F.) & 1 & 1.39 \\
Comercializadora (Villa Juarez, Zac.) & 1 & 1.39 \\
Exportadora en Aguascalientes & 1 & 1.39 \\
La Piedad (Mich.) & 1 & 1.39 \\
se vende su propio (direct sales) & 2 & 2.78 \\
\hline
\end{tabular}

chiles). Farmers report current Ancho hybrids needing 8 to $10 \mathrm{~kg}$ of fresh chiles to yield $1 \mathrm{~kg}$ of dry (J. Luna Ruíz and K. Kraft, unpublished data).

The fresh vegetable market demands uniform and consistent products. For green chiles, this encourages the use of hybrid varieties, which guarantee that each seed purchased has the same genotype and produces identically shaped fruits. However, although dried chiles are sold alongside fresh chiles, there are not the same demands on dried chiles. The drying process is forgiving and allows for heterogeneity in the morphological characteristics of the fruit. Fruit blemishes or color variation are less of a concern for dried chiles. This allows for more genotypes and varieties of dried chiles to be grown, yet all are sold as a single type. For example, genotypes identified by farmers as pasilla included "Querétaro," "Queréndaro," and "Negro"; yet are all bulked and sold as pasilla peppers.

\section{Seed Replacement}

Of the farmers who saved seed, some $40 \%$ do not practice any field selection. All of their seed selection is postharvest. From a breeding standpoint, the lack of any field selection might be considered inefficient, even antithetical to the improvement and longevity of the variety. Indeed, farmers complain about the lack of longevity of their seed stocks, stating that after three or four years, they need to replace all of their seed because "son muy degenerados"- the seeds are degenerated, or "tired." There is a belief that seed lots cannot be planted year after year after year, that the seed "tires" and must be renewed. This renewal comes from bringing in seed that has not been used locally for some time. The farmers who comprised the minority that practiced selection in the field as well as selection of fruit and seeds, had only recently adopted the practice, a result of a pilot workshop developed by a recent collaboration between the Sistema Producto Chile and the Universidad Autónoma de Aguascalientes.

While traditional selection techniques-postharvest selection-may have been sufficient to maintain ideotypes and stable levels of yield for periods of time, farmers need another tool to remain competitive. The wide range of locations identified as seed sources show the lengths that farmers will go to try and obtain higher yields. Given the success of the first workshop given by the University (farmers who performed field, fruit, and seed selection mentioned taking the workshop), it is clear that there exists a tremendous opportunity for the University to recognize and support the informal seed sector. To slightly rephrase Cleveland and Soleri (2007), the goal is to link the public institution breeders' focus on evolution and directed selection with the farmers' on production and marketing. Everyone wants the same outcome-the continued cultivation of criolla varieties-but there needs to be a mutual understanding before both groups can successfully work together.

\section{Differing Conceptions of Selection amONG Farmers and SCIENTISTS}

Cleveland and Soleri (2007) identified some barriers among farmers, biologists, and plant 
breeders that impede our collective understanding of the process of crop selection by farmers and our progress towards truly linking crop genetic resource conservation and participatory breeding efforts. One important point raised by the authors was that selection by farmers is not always part of a progression towards evolution and changes in gene frequencies. For instance, in a study of maize farmers in the village of Cuzalapa (southern highlands of the state of Jalisco, Mexico), farmer selection was found to be a way of maintaining the "legitimacy" or ideotypes of local varieties (Louette and Smale 2000). They found that farmers do not select in the field, rather they select the harvested ears that are full of grain and "typical" of the ideotype. When asked their principal reasons for selecting and saving seed, they identified increases of seed quality and germination and for maintaining the ideotype.

The farmers interviewed in Cuzalapa do not perceive seed selection as a means of modifying a variety. For them a variety is stable and cannot be modified; modifying it would make it another variety.

\section{—Louette and Smale 2000, pg. 38}

There was little conception of the potential for modifying characteristics through repeated selection of the same seed. Rather, only through wholesale seed exchange could one modify and change traits.

This static notion of a variety was evident in the attitudes encountered with the chile farmers surveyed in Aguascalientes. In this study, the fruit selection criterion identified by farmers to be most commonly used after fruit size, which indirectly selects for yield, was forma, or fruit shape. This can be viewed as selection to maintain the characteristic shape of the pod conforming to the ideotype of each chile variety. In contrast, many breeders or scientists view selection as a more directed process something akin to evolution (Cleveland and Soleri 2007) but also a process to maintain the characteristics of a given cultivar. The idea that farmers do not solely practice directional selection identifies our own biases in the way that we conceive of selection.

\section{Conclusions}

This survey instrument was utilized to understand chile producers' seed saving behavior and their selection process in Aguascalientes. Are there differences in how farmers maintain and select seed? Unequivocally, the answer is yes. Farmers can be divided by the type of chiles that they are producing-fresh or dried. Farmers producing fresh chiles do not save seed, rather they purchase seed as they do for other inputs to their production system. While landraces of green/ fresh chile were once planted in the region (some respondents say even 10 to 15 years ago), landraces of green chile were not currently planted by any of the survey respondents. On the other hand, farmers who produce dried chile show variation in the way they approach seed selection. Of all the farmers, $40 \%$ practice only one level of selection (in the field only or only selecting on fruit characteristics). A small minority of farmers employs all three levels of selection (field, fruit, and seed). Farmers who save seed typically plant their seed lots for four to five years, before replacing it completely with seed from foreign sources.

Are there factors that explain the differences in seed saving and selection? While there was a marked difference in the demographics of those who plant hybrids (younger, more educated) versus those who plant criolla seeds (older, less education), getting at the differences in the selection behavior is more difficult. Looking solely at the farmers who cultivated criolla varieties, a number of them identified a recent training program as the impetus for them to be more "rigorous" in their selection practices. Indeed, the two other farmers with "rigorous" selection practices had training in university agronomy classes. These farmers had different conceptions of selection; rather than using it as a tool to maintain the ideotype, they use it as a tool to keep improving agronomic characteristics, such as disease resistance and yield.

What are the mechanisms by which farmers maintain and generate diversity? In this system, diversity is generated by bringing in external material_criolla seed from neighboring states or from other towns.

\section{ImPlications for Genetic Resources CONSERVATION}

While these landraces and local varieties are not immediately threatened, we only need to look at the recent fate of green chile landraces in the state of Aguascalientes to remind us how quickly a situation can change.

Conventional conceptions of in-situ conservation would promote the integrity of the system 
and attempt to exclude foreign genetic material. Reviewing this case with chile peppers in the state of Aguascalientes, there is a general lack of fealty to their own seed lots. Farmers are constantly willing to try seeds; they are always looking and listening for seeds that perform better than the ones they have. The concept of genetic erosiona loss of genetic diversity due to decreasing population size or the replacement of varieties by modern varieties - has been brought out as a threat that we collectively need to fight. However, the relationship between external varieties and genetic erosion is not that simple (Louette et al. 1997). Indeed, the concept of genetic erosion rests on an idealized picture of a farmer who maintains diversity through his/her own seed selection and seed saving practices (Brush 2004). Louette et al. (1997) posited that if the foreign introduction had a complementary role, little or no reduction in the number of varieties planted would result. In contrast, if the introduction of foreign material were in direct competition to the local varieties, it would displace the extant varieties. It is clear in this case that the introduction of criolla foreign material brings diversity to the system and even sustains the system, as the notion and definition of a local variety has to be expanded both in time and geographical space. In contrast, as we look to the example and lesson learned by the displacement of green chile landraces, too much of a good thing can be bad-the introduction of hybrid seeds that are targeted at the dried chile market can and will eliminate the little landrace diversity that is observed.

\section{Acknowledgements}

K. Kraft would like to acknowledge IIE Fulbright Program and the UC Davis Department of Plant Sciences for funding this research, the Comité Estatal de Sanidad Vegetal de Aguascalientes for their assistance in identifying survey participants and the participants themselves for taking the time to talk and answer questions.

\section{Open Access}

This article is distributed under the terms of the Creative Commons Attribution Noncommercial License which permits any noncommercial use, distribution, and reproduction in any medium, provided the original author(s) and source are credited.

\section{Literature Cited}

Abay, F., A. Waters-Bayer, and A. Bjornstad. 2008. Farmers' seed management and innovation in varietal selection: Implications for barley breeding in Tigray, northern Ethiopia. Ambio 37:312-320.

Almekinders, C. J. M. and A. Elings. 2001. Collaboration of farmers and breeders: Participatory crop improvement in perspective. Euphytica 122:425-438.

Bai, Y. L. and L. Pim. 2007. Domestication and breeding of tomatoes: What have we gained and what can we gain in the future? Annals of Botany 100:1085-1094.

Bellon, M. R. 1996. The dynamics of crop infraspecific diversity: A conceptual framework at the farmer level. Economic Botany 50:26-39.

- J. Berthaud, M. Smale, J. A. Aguirre, S. Taba, F. Aragon, J. Diaz, and H. Castro. 2003. Participatory landrace selection for onfarm conservation: An example from the Central Valleys of Oaxaca, Mexico. Genetic Resources and Crop Evolution 50:401-416.

Brush, S. 2004. Farmer's Bounty-Locating crop diversity in the contemporary world. Yale University Press, New Haven and London.

_ and E. Meng. 1998. Farmers' valuation and conservation of crop genetic resources. Genetic Resources and Crop Evolution 45:139-150.

Cabañas Cruz, B. and G. Galindo Gonzales. 2004. Technological level of dry Capsicum annuum growers in the Zacatecas Highlands. León, Guanajuato, Mexico: First World Pepper Convention. http://www.world-pepper.org/2004/ memorias2004/269_cabanas_cruz_wpc2004. pdf (30 March 2010).

Cleveland, D. A. and D. Soleri. 2007. Extending Darwin's analogy: Bridging differences in concepts of selection between farmers, biologists, and plant breeders. Economic Botany 61:121-136.

D. Soleri, and S. E. Smith. 2000. A biological framework for understanding farmers' plant breeding. Economic Botany 54:377-394.

Conaghan, P., M. D. Casler, P. O'Kiely, and L. J. Dowley. 2008. Efficiency of indirect selection for dry matter yield based on fresh matter yield in perennial ryegrass sward plots. Crop Science 48:127-133.

Dyer, G. A. and J. E. Taylor. 2008. A crop population perspective on maize seed systems 
on Mexico. Proceedings of the National Academy of Sciences of the United States of America 105:470-475.

INEGI. 2005. Anuarios Estadítsticos del Estado de Aguascalientes, Edición 2005. INEGI, Aguascalientes.

Jarvis, D. I. and T. Hodgkin. 1999. Wild relatives and crop cultivars: Detecting natural introgression and farmer selection of new genetic combinations in agroecosystems. Molecular Ecology 8:S159-S173.

Levy, P. S. and S. Lemeshow. 1991. Sampling of populations: Methods and applications. Wiley, New York.

Louette, D. and M. Smale. 2000. Farmers' seed selection practices and traditional maize varieties in Cuzalapa, Mexico. Euphytica 113:25-41.

_, A. Charrier, and J. Berthaud. 1997. In Situ conservation of maize in Mexico: Genetic diversity and maize seed management in a traditional community. Economic Botany 51:20-38.

Microsoft Corporation 2007. Microsoft Excel 2008 for Mac.
Perales, H., S. B. Brush, and C. O. Qualset. 2003. Dynamic management of maize landraces in Central Mexico. Economic Botany 57:21-34.

Perry, L. and K. V. Flannery. 2007. Precolumbian use of chili peppers in the Valley of Oaxaca, Mexico. Proceedings of the National Academy of Sciences of the United States of America 104:11905-11909.

SAS Institute. 1989-2004. JMP-The Statistical Discovery Software. Release 5.1.2. Cary, North Carolina: SAS Institute. 2002-2003. SAS. Release 9.1.3. Cary, North Carolina: SAS Institute.

Teshome, A., L. Fahrig, J. K. Torrance, J. D. Lambert, T. J. Arnason, and B. R. Baum. 1999. Maintenance of Sorghum (Sorghum bicolor, Poaceae) Landrace Diversity by Famers' Selection in Ethiopia. Economic Botany 53:79-88.

Zygier, S., A. B. Chaim, A. Efrati, G. Kaluzky, Y. Borovsky, and I. Paran. 2005. QTLs mapping for fruit size and shape in chromosomes 2 and 4 in pepper and a comparison of the pepper QTL map with that of tomato. Theoretical and Applied Genetics 111:437-445. 